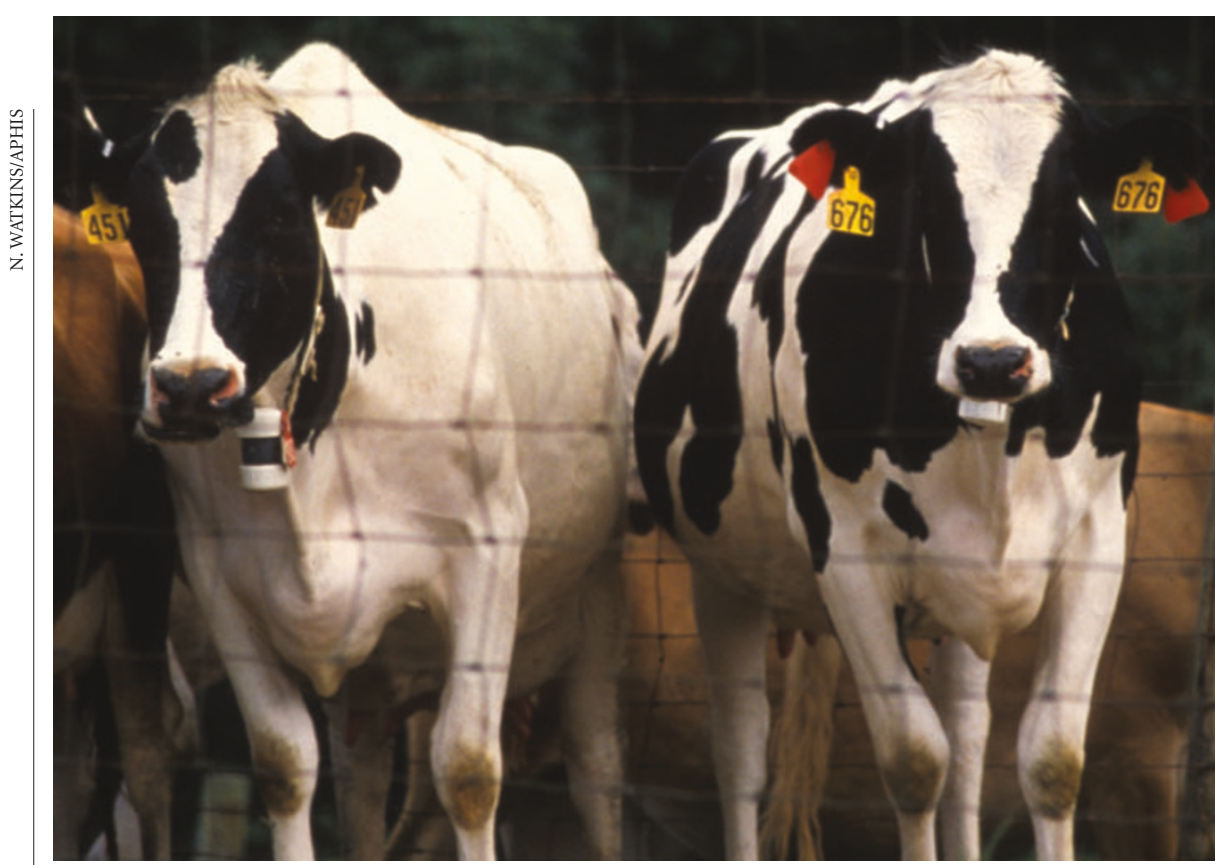

High stakes: the United States has been advised to expand its monitoring of cattle herds for disease.

\title{
Food panel calls for beefed up response to mad cow disease
}

Erika Check, Washington

An international panel of experts is urging the US Department of Agriculture (USDA) to take extra measures to block the spread of mad cow disease. But the department looks unlikely to comply, after a domestic advisory group expressed scepticism about the scientists' suggestions.

Ulrich Kihm, Switzerland's chief veterinary officer and chair of the international panel, says that there are sure to be more diseased cows in the United States than the one found in Washington state in December. "There is no question that there are many more out there," he says.

In a report released on 4 February, Kihm's group said that the United States should expand its cattle surveillance programme and put extra restrictions on the types of animal products that can be fed to livestock and pets.

The panel was invited to review the US response to mad cow disease, or bovine spongiform encephalopathy (BSE), shortly after the Washington case was diagnosed. Agriculture secretary Ann Veneman asked it to assess whether the US investigation conformed to international standards and to recommend further steps that might be taken.

But the USDA's Advisory Committee on Foreign Animal and Poultry Diseases, which received the report at a meeting near Washington, wasn't impressed with the panel's findings. "We've had tens and tens of thousands of animals tested since 1997," said committee member Tobin Armstrong, a rancher in Texas. "If you want to measure the extent of the problem, you have to go on those numbers - and the number is one."
The National Cattlemen's Beef Association issued a statement saying that the four overseas members on the five-strong expert panel had underestimated the measures already in place to block BSE. "Many of the panel's recommendations are based on the European model and overlook scientific evidence that clearly demonstrates the longstanding firewalls in place in our country have been effective," it said.

Since December, the USDA has brought in a series of rules to bolster defences against both BSE and its human equivalent, variant Creutzfeldt-Jakob disease. It has banned the slaughter for beef of animals that are too sick to walk, and farmers now cannot sell parts of older cows' central nervous systems as food.

But Kihm's review panel says that's not enough. It argues that other infected cows were probably turned into cow meal before rules enacted in 1997 prohibited the use of cow parts in cattle feed. It adds that feed bans have been difficult to enforce in Europe.

The panel also questioned the USDA's plan to test just 40,000 high-risk cattle over the next year. It says that officials should consider testing all cows over 30 months old in certain high-risk populations, as well as a sample of other, older animals.

"You'd need to test a very large sample of fallen stock to get a good idea of the real situation," says Marc Savey, research director at the French Food Safety Agency. "It should be more like 800,000 to 3 million animals 40,000 is ridiculous."

Veneman's advisory committee will now review the international team's report and make its own recommendations.
Pacific dolphins make waves for US policy on Mexican tuna

Virginia Gewin, Portland

Conservationists are accusing the US government of ignoring its own scientific advisers over its decision to import tuna fish from Mexico.

In December 2002, the Department of Commerce agreed that tuna from Mexico could be labelled 'dolphin safe' and so be imported and sold in the United States.

But a conservation organization last week revealed a cache of documents that suggest this decision was taken against scientific advice.

Biologists want the imports banned because Mexican fishermen target and chase dolphins in order to catch the underlying tuna. They argue that this is contributing to the decline in dolphin numbers in the Pacific Ocean.

The papers were circulated by the Earth Island Institute, a conservation group in San Francisco and one of several plaintiffs suing the government over the issue, after they were released by a district court judge in San Francisco towards the end of last year. They are a "smoking gun", according to the institute's director, David Phillips.

The documents list talking points for briefings prepared by officials for the commerce secretary, Donald Evans. One states: "We've all seen the science. We know that dolphins aren't recovering." Another says that "a determination of 'no significant adverse impact' is not supported by the science".

The issue was analysed by the Southwest Fisheries Science Center, a San Diego-based research arm of the National Marine Fisheries Service (NMFS). Its report, released in August 2002, said that indirect effects of tuna fishing such as stress could explain declining dolphin populations in the Pacific.

A five-member independent expert panel unanimously agreed with these findings, and the current lawsuit is backed by three members of this panel.

But the commerce department got different advice from the Inter-American Tropical Tuna Commission, which is funded by governments to maintain maximum sustainable tuna catches in the Pacific. It contends that if Mexican fishermen adopted new fishing methods, it would damage marine ecosystems further.

NMFS director William Hogarth maintains that the initial import decision was justified, but neither he nor the chief scientist from the Southwest Center would comment further pending the district court hearing on 29 March. 